\title{
The Study of Women and Music in Morocco Alessandra CiUCCI
}

Departments of Music, Sociology, and Anthropology, and International Affairs, Northeastern University, Boston, Mass.; e-mail: a.ciucci@neu.edu doi:10.1017/S0020743812000906

The 1987 publication of Women and Music in Cross-Cultural Perspectives, the first anthology on the topic of women and music in the field of ethnomusicology, marked a critical turn in the scholarship. ${ }^{1}$ The ethnographic-focused essays on women's genres and roles in music in diverse societies around the world, including the Middle East, presented new analytical frameworks and research on authority, gender and access, and notions of power and performance. Today, research on the musical practices of women continues to expand in ethnomusicology and in fields such as anthropology. Many scholars now acknowledge the centrality of gender for locating "how society is in music and music is in society." This is a particularly important approach for the Middle East and North Africa, where the undervaluing or silencing of women's musical practices and abilities had continued to dominate ethnomusicology. An important study to break from the paradigm was Virginia Danielson's 1997 monograph on Umm Kulthum. ${ }^{2}$ Danielson analyzes the development and the construction of a musical and a social "voice," looking at what it means for this particular artist to both be the voice of and have a voice in colonial and postcolonial Egypt. In the discussion that follows I outline the academic trajectory of writings on women and music in Morocco, which I have divided into three distinct historical moments, each exemplifying different approaches to the subject matter: work by 20th-century French colonial scholars, by contemporary European and American scholars, and by contemporary Moroccan scholars.

Early 20th-century colonial writings on the musical practices of women in Morocco took their cues from the descriptions of performances in the travelogues of Europeans involved, directly or indirectly, with the French Protectorate, descriptions that were inevitably tainted by Western moralism and Oriental stereotypes. ${ }^{3}$ This type of writing is exemplified by the work of the French musicologist Alexis Chottin, the head of the National Conservatory in Rabat who published important work on the music of Morocco under the aegis of the colonial administration's Service des Arts Indigènes. ${ }^{4}$ Chottin was primarily interested in al-āla or al-mūsìq $\bar{a}$ al-andalusiyya, a cultivated music tradition that is highly esteemed in Morocco; indeed, he neglected a number of musical genres that were not associated with this tradition. In his works Chottin either glossed over the musical practices of women or associated them with debauchery and prostitution:

We will meet the libertine and sensual Morocco. This "face" is pleasant-looking . . . And I'm really afraid, alas! that underneath there's nothing but a poor and little face, a pallid and wrinkled pleasure-seeker, who is consumed by the pursuit of an impossible sensual bliss. In the quiet mediocre poems she sings, there is always a cruel female who obstinately refuses to grant anything to a suitor who is eternally rejected ... This laugh and this joy blend and burst in the rhythm, dizzying rhythm, enchanting rhythm that lulls worries and sorrows; vampire-rhythm whose wings flutter to anesthetize the pain caused by its fatal bite. ${ }^{5}$

As Chottin's phantasmagorical narrative transforms the sensual female performer into a wrinkled pleasure seeker and the enchanting rhythm of the musical repertoire she 
performs into the rhythm of vampires, the musical practices of Moroccan women are articulated through "the deforming lens of Orientalism."

European and American scholars working on postcolonial Morocco have produced a rather diverse body of literature related to women and music. Miriam Rovsing-Olsen's work suggests that the neutralization of gender in the ahwash-the communal song and dance celebration of the Berbers of southwestern Morocco-is illustrated by the repertory of songs that both men and women perform and by the division of the night of an ahwash into two equal parts: one devoted to men and the other to women. ${ }^{7} \mathrm{~A}$ study by Tony Langlois describes how an Aissawa trance ceremony involving music and dancing in Oujda offers women some respite from the frustration and anxiety of everyday existence. ${ }^{8}$ Antonio Baldassarre, who examines the involvement of an allfemale ensemble from Marrakesh in the world music circuit, argues that this case study represents the transformation of the role of particular female musicians in Morocco. ${ }^{9}$ Filling an earlier void of research on women's ensembles that perform on melodic instruments, Julia Banzi has documented the participation of female instrumentalists in contemporary Andalusian ensembles in Tetouan, arguing that despite the encroaching male appropriation of the female repertoire, the persistence of these female ensembles indicates the engagement of women in a specific musical practice. ${ }^{10}$ My own work on a musicopoetic genre ('aita) performed by professional female singer-dancers (shikhat) illustrates how, as it becomes officially incorporated into the national heritage, the 'aita is turned into a contested site where gender, morality, and the state intersect. ${ }^{11}$ Recent works by anthropologists have analyzed the performative aspects of music in order to illustrate the role of the shikhat in challenging the Moroccan moral system in the course of performance ${ }^{12}$; how songs work as strategic devices for Berber women in the Rif mountains of northern Morocco to have a voice and gain control over their lives ${ }^{13}$; and the way they allow Tashelhit-speaking Berber women from the Anti-Atlas mountains of southwestern Morocco to engage with a moral economy grounded in a particular community. ${ }^{14}$

Moroccan academics have often included some discussions on women and music in comprehensive studies on particular traditions. ${ }^{15}$ In the case of the 'aita, however, the shikhat have become crucial to their analysis. ${ }^{16}$ With the exception of Khadija Abdeljamil, who concludes her linguistic study by commenting on how the marginal status of the shikhat is linked to the eroticism of their performance, other academics from a variety of disciplines have approached the caita as a historical object so as to revalorize it. This scholarship has argued that the 'aita was denigrated as a result of the way in which French colonists experienced it-they emphasized the sensuality of the shikhat's dances and minimized the poetic text sung by female performers. The efforts of these academics have intersected with the official cultural politics of the Ministry of Culture, which since 1999 has actively promoted the construction of an all-inclusive national culture. ${ }^{17}$ In their writings on women and music the aim of many Moroccan scholars has been motivated by both postcolonial concerns - the reappropriation of a musico-poetic genre from the colonizers-and a moral interest in recovering the honor of Moroccan women.

The academic trajectory of writings that I have outlined in this brief survey both illustrates how music provides a crucial setting for observing and understanding the gender structure of a society and calls attention to the fact that, because what we hear 
and interpret is historically and culturally determined, in studying music we are both participants in shaping the object and strategists for its investigation. ${ }^{18}$

\section{NOTES}

${ }^{1}$ Ellen Koskoff, ed., Women and Music in Cross-Cultural Perspective (New York: Greenwood Press, 1987).

${ }^{2}$ Virginia Danielson, The Voice of Egypt: Umm Kulthum, Arabic Song, and Egyptian Society in the Twentieth Century (Chicago: University of Chicago Press, 1997).

${ }^{3}$ Eugène Aubin, Le Maroc d'aujourd'hui (Paris: A. Colin, 1904); Christian Houël, Maroc: Mariage, adultère, prostitution-Anthologie (Paris: H. Daragon, 1912).

${ }^{4}$ Alexis Chottin, Tableau de la musique marocaine (Paris: Paul Geuthner, 1939).

${ }^{5}$ Alexis Chottin, "Les visages” de la musique marocaine (Rabat: Imprimerie Nouvelle, 1928), 11.

${ }^{6}$ Edmund Burke, "The Creation of the Moroccan Colonial Archive, 1880-1930," History and Anthropology 18 (2007): 2 .

${ }^{7}$ Miriam Rovsing-Olsen, "Contemporary Issues of Gender and Music," in Garland Encyclopedia of World Music: The Middle East, ed. Virginia Danielson, Scott Marcus, and Dwight Reynolds (New York: Routledge, 2002), 299-307.

${ }^{8}$ Tony Langlois, "Heard but not Seen: Music among the Aissawa of Oujda, Morocco," Music and Anthropology 4 (1999), http://www.muspe.unibo.it/period/ma/index/number4/ma_ind4.htm.

${ }^{9}$ Antonio Baldassarre, "With the Daughters of the Houara (Morocco): From Fieldwork to World Music," Music and Anthropology 4 (1999), http://www.muspe.unibo.it/period/ma/index/number4/ma_ind4.htm.

${ }^{10}$ Julia Banzi, "Women's Andalusian Ensemble of Tetuan, Morocco" (master's thesis, University of California, Santa Barbara, 2002).

${ }^{11}$ Alessandra Ciucci, "Poems of Honor, Voices of Shame: The 'Aita and the Moroccan Shikhat" (PhD diss., The Graduate Center, City University of New York, 2008).

${ }^{12}$ Fanny Soum-Pouyalet, Le corps, la voix, le voile: Cheikhat marocaines (Paris: CNRS, 2007); Deborah Kapchan, Gender on the Market: Moroccan Women and the Revoicing of Tradition (Philadelphia, Pa.: University of Pennsylvania Press, 1996).

${ }^{13}$ Terry Brint Joseph, "Poetry as a Strategy of Power: The Case of Riffian Berber Women," Signs 5 (1980): 418-34.

${ }^{14}$ Katherine Hoffman, "Generational Change in Berber Women's Song of the Anti-Atlas Mountain, Morocco," Ethnomusicology 46 (2007): 510-40.

${ }^{15}$ In his most recent work the musicologist Ahmed Aydoun discusses the role of women in a musico-poetic and dance tradition practiced among the Saharawi population from southern Morocco. See Ahmed Aydoun, Azawan, la musique hassanie. Voyage au cœur du Maroc saharien (Rabat: Editions DTGSN, 2011).

${ }^{16}$ Hasan Najmi, Ghina' al- 'Aita: al-Sh ir al-Shafawi wa-l-Musiqa al-Taqlidiyya fi al-Maghrib (Casablanca: Dar Tubqal li-1-Nashr, 2007); Hasan Bahrawi, Fann al-'Aita fi al-Maghrib: Musahama fi al-Ta'rif (Rabat: Ittihad Kitab al-Maghrib, 2002); 'Allal Rakuk, al-Ghina’ al-Sh'abi al-Maghribi: Anmat wa-Tajalliyat (Rabat: Maktabat al-Talib, 2000); Muhammad Bu Hamid [Buhmid], "Innahum Yuridun al-'Aita ka-Dajij li-Jami' alHushud," al-Ittihad al-Ishtiraki (April 1995): 6. Khadija Abdeljamil, "L'énonciation dans la chanson populaire arabe de femmes au Maroc (chikhat)" (PhD diss., Université Lumière-Lyon II, 1993).

${ }^{17}$ Alessandra Ciucci, "De-orientalizing the 'Aita and Re-orienting the Shikhat," in French Orientalism: Culture, Politics, and the Imagined Other, ed. Desmond Hosford and Chong J. Wojtkowski (Newcastle upon Tyne, U.K.: Cambridge Scholars Press, 2010), 71-96.

${ }^{18}$ Adelaida Reyes, "What Do Ethnomusicologists Do? An Old Question for a New Century," Ethnomusicology 53 (2009): 12-13. 